\title{
New aid for diagnosing chronic beryllium disease (CBD): laser ion mass analysis (LIMA)
}

\author{
W JONES WILLIAMS, * D KELLAND \\ From the *University of Wales College of Medicine, Pathology Department, Llandough Hospital, Penarth, \\ South Glamorgan, and the Department of Metallurgy and Material Sciences, University of Cambridge, \\ Cambridge
}

SUMMARY The value of laser ion mass analysis (LIMA) for the detection of beryllium disease ify routine histological sections was investigated. Our results were based on the examination of 14 cases of confirmed and five cases of suspected chronic beryllium disease. With the exception of two cases of coal workers' lungs, all the control material, normal, tuberculous, and sarcoid lungs examineक्ष were free of beryllium. The technique may also be useful in other diseases of possible occupationaib origin.

The following criteria have been advocated for the diagnosis of chronic beryllium disease $(\mathrm{CBD})^{1}$ : history of exposure; consistent clinical and radiological features; microscopic evidence of epithelioid cell granulomas in affected tissue; evidence of sensitisation, as shown by a positive beryllium lymphocyte transformation test (BeLT); ${ }^{2}$ detection of beryllium in the tissues. The first and second criteria are mandatory. Unfortunately, the microscopic features are not diagnostic and evidence of sensitisation, though proving exposure, does not necessarily prove disease. The detection of beryllium is often difficult; there is often insufficient tissue for bulk spectroscopic analysis, histochemical methods are unreliable, and energy dispersive analysis generally does not detect light elements below atomic weight $11(\mathrm{Be}=9)$. The laser ion mass analysis (LIMA) technique, (Cambridge Mass Spectrometry Limited) which can detect beryllium as low as parts per million, thus offers considerable advantages.

\section{Material and methods}

LIMA uses a pulsed microfocused laser beam to ionise a small volume $\left(\mu \mathrm{m}^{3}\right)$ of material. The ions released are detected by a time of flight mass spectrometer, producing a complete mass spectrum of all elements in the periodic table with a sensitivity range from 1-10 parts per million. ${ }^{3}$

We used conventional $5 \mu \mathrm{m}$ histological sections mounted (preferably) on plastic (melamine) film or on glass slides. The sections were viewed through a standard optical microscope, and the micron diameter laser beam was directed as required. Spectra can thus be obtained from individual or groups of cells, such as granuloma, and values compared with those of adjacent normal tissue. Multiple (up to 50)

areas were examined in each case, yielding results, which currently are qualitative and not quantitative

We examined three major groups of cases: definite cases (14 patients with chronic beryllium disease whछ satisfy the diagnostic criteria); suspect cases (five patients with incomplete evidence of chronic beryl ${ }_{\infty}^{\circ}$ lium disease); 13 control subjects, including two witl normal lungs, one with tuberculous lung, two witlo coal miners' lungs (one with simple and one witl progressive massive fibrosis), and seven patients wit/ sarcoidosis.

\section{Results (Table)}

We detected beryllium in 13 of the 14 definite cases 3 The negative result in case 11 with a positive bulke analysis was surprising. A repeat test for case $11 \mathrm{wa}$. carried out, which gave a positive result. The BeL test was positive in eight of 10 tested, and all eight were LIMA positive. Both BeLT negative cases were LIMA positive.

In the suspect group only case 20 was LIMA posi tive (also positive by spectroscopy). The patient dieo from rheumatoid pulmonary fibrosis without any evidence of granulomas. The BeLT test was negative in all four patients tested.

Of the 13 control subjects, beryllium was absent if the two with normal lungs, one with tuberculous lung and seven with sarcoidosis lungs (with granulomas) Both samples of coal workers' pneumoconiosis were LIMA positive. Beryllium was not detected in the plastic film, glass slides, haematoxylin and eosin an toludine blue stains.

\section{Discussion}

Our results confirm a previous report that micro $\frac{\mathbb{\Phi}}{\mathbb{D}}$

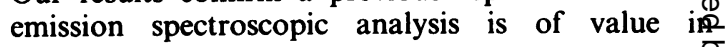


New aid for diagnosing chronic beryllium disease

Table LIMA analysis in patients with beryllium disease

\begin{tabular}{|c|c|c|c|c|c|c|c|}
\hline UK case No & $L I M A$ & Be exposure & Site & Histology & Spectroscopic & $B e L T$ & Diagnosis \\
\hline $\begin{array}{l}\text { Definite cases } \\
11 \\
13 \\
17 \\
23 \\
36 \\
41 \\
45 \\
47 \\
48 \\
49 \\
50 \\
51 \\
52 \\
53\end{array}$ & $\begin{array}{l}- \\
+ \\
+ \\
+ \\
+ \\
+ \\
+ \\
+ \\
+ \\
+ \\
+ \\
+ \\
+ \\
+\end{array}$ & $\begin{array}{l}\text { Fluorescent tubes } \\
\text { Machinist } \\
\text { Machinist } \\
\text { Machinist } \\
\text { Machinist } \\
\text { Machinist } \\
\text { Fluorescent tubes } \\
\text { Ceramic } \\
\text { Chemist } \\
\text { Fluorescent tubes } \\
\text { Fluorescent tubes } \\
\text { Ceramic } \\
\text { Machinist } \\
\text { Ceramic }\end{array}$ & $\begin{array}{l}\text { Lung } \\
\text { Skin } \\
\text { Lung } \\
\text { Lung } \\
\text { Lung } \\
\text { Lung } \\
\text { Lung } \\
\text { Skin } \\
\text { Lung } \\
\text { Lung } \\
\text { Lung } \\
\text { Skin } \\
\text { Skin } \\
\text { Skin }\end{array}$ & $\begin{array}{l}+ \\
+ \\
+ \\
+ \\
+ \\
+ \\
+ \\
+ \\
+ \\
+ \\
+ \\
+ \\
+ \\
+\end{array}$ & $\begin{array}{l}+ \\
+ \\
+ \\
\text { ND } \\
\text { ND } \\
+ \\
+ \\
\text { ND } \\
\text { ND } \\
\text { ND } \\
\text { ND } \\
\text { ND } \\
\text { ND } \\
\text { ND }\end{array}$ & $\begin{array}{l}\text { ND } \\
+ \\
+ \\
\text { ND } \\
+ \\
- \\
\text { ND } \\
+ \\
+ \\
+ \\
\text { ND } \\
+ \\
+ \\
+\end{array}$ & \\
\hline $\begin{array}{l}\text { Suspect cases } \\
3 \mathrm{~s} \\
20 \mathrm{~s} \\
38 \mathrm{~s} \\
39 \mathrm{~s} \\
44 \mathrm{~s}\end{array}$ & $\begin{array}{l}\overline{+} \\
- \\
-\end{array}$ & $\begin{array}{l}\text { Metallurgist } \\
\text { Air sampler } \\
\text { Machinist } \\
\text { Machinist } \\
\text { Machinist }\end{array}$ & $\begin{array}{l}\text { Lung } \\
\text { Lung } \\
\text { Skin } \\
\text { Skin } \\
\text { Skin }\end{array}$ & $\begin{array}{l}+ \\
- \\
- \\
+\end{array}$ & $\begin{array}{l}\text { ND } \\
+ \\
\text { ND } \\
\text { ND } \\
\text { ND }\end{array}$ & $\begin{array}{l}- \\
- \\
\text { ND } \\
-\end{array}$ & $\begin{array}{l}\text { Sarcoid (Kveim positive) } \\
\text { Rheumatoid disease } \\
\text { Scar } \\
\text { Scar } \\
?\end{array}$ \\
\hline
\end{tabular}

detecting beryllium disease in tissue sections. ${ }^{4}$ With the advent of a new technique, the laser microprobe (LIMA), the routine detection of beryllium is possible as low as parts per million. Our positive mass spectra were obtained from analysing granulomas, but not all in a given section were positive. The background lung usually gave negative results (to be confirmed). There is always, therefore, the possibility of sampling error, which will be less if there is enough tissue for bulk analysis, and this may explain our failure in case 11 . Positive LIMA analyses confirmed the spectroscopic findings in the four other cases with bulk analyses. The positive results in the two cases of coal workers' pneumoconiosis were expected as coal contains small quantities of beryllium. ${ }^{5}$ It is therefore important to avoid areas of coal dust in future examination of suspected beryllium tissue.

Our technique is of considerable value in patients with suspected disease. Of the five suspected cases tested by LIMA, one gave a positive result (case 20s), which was also positive on bulk analysis. This problem patient had extensive rheumatoid arthritis and died from cor pulmonale resulting from diffuse interstitial fibrosis without any evidence of old or fresh granulomas in the lung or other tissue. Despite the history of exposure and the finding of $\mathrm{Be}$ in the lungs the absence of granulomas and a negative BeLT test precludes a definite diagnosis.

In case 3s our negative LIMA result was of value in excluding beryllium disease and suggestive of sarcoidosis in a metallurgist with possible but unconfirmed Be exposure. Three machinists developed scars and nodules on the fingers resulting from old injuries. In only one (case 44s) were granulomas found on biopsy, so that our negative result needs to be re-examined for other causes, in particular, sarcoidosis in a scar.

We also related the BeLT test of hypersensitivity to the LIMA results. In the definite group all BeLT positive patients were LIMA positive, but two LIMA positive subjects were BeLT negative. Of the suspect patients, the BeLT test was negative in two patients with granulomas and the one patient who was LIMA positive. The results confirm our impression that not all patients with beryllium show hypersensitivity.

Our control series will be extended to include further examination of normal lungs and other granulomatous diseases. The negative $\mathrm{Be}$ analysis in the seven patients sarcoidosis is important as the granulomas are indistinguishable from those of beryllium disease. ${ }^{6}$ Future developments will include quantification.

In conclusion, we consider that this technique offers exciting possibilities, not only in the differential diagnosis of beryllium disease but for determining causative agents in other possible occupational diseases.

Mr Kelland acknowledges the Science and Engineering Research Council for financial support and Professor D Hull for provision of research facilities. We are also grateful to Mr M Saunders, Llandough Hospital, for the preparation of the slides.

\section{References}

${ }^{1}$ Jones Williams W. Beryllium disease-pathology and diagnosis. J Soc Occup Med 1977;27:93-6.

2 Jones Williams W, Williams WR. Value of beryllium lymphocyte transformation test in chronic beryllium disease and potentially exposed workers. Thorax 1983;38:41-4.

${ }^{3}$ Southon MS, Witt MC, Harris A, Wallach ER, Myatt J. Laser microprobe mass analysis of surface layers and bulk solids. Vacuum 1984;34:903-9.

${ }^{4}$ Robinson FR, Solomon F, Brokeshoulder SF, Thomas AA, Cholak J. Microemission spectrochemical analysis of human lungs for beryllium. Am J Clin Pathol 1968;49:821-5.

${ }^{5}$ Chatterjee TK, Pooley FD. Examination of some trace elements in South Wales coals. Proceeding of the Australian Institute of Mining and Metallurgy 1977;263:19-30.

${ }^{6}$ James DG, Jones Williams W. In: Sarcoidosis and other granulomatous disorders. Major problems in internal medicine. Philadelphia: WB Saunders, 1985

Requests for reprints to: Professor W Jones Williams, Pathology Department, Llandough Hospital, Penarth, South Glamorgan, Wales. 